\title{
Pelaksanaan Implementasi Lesson Study Di Kelas 7
}

\section{J. Tosi ${ }^{1}$, A. K. Adti ${ }^{2}$, I. G. Budasi ${ }^{3}$}

12 Jurusan Pendidikan Bahasa Inggris Universitas Pendidikan Ganesha

\section{ART I CLE INF O}

Article history:

Received January 21, 2021

Revised February 03, 2021

Accepted April 08, 2021

Available online May 25, 2021

Kata Kunci:

Lesson Study, Peningkatan,

Pembelajaran

Keywords:

Lesson Study,

Improvement, Learning

\section{A B S T R A K}

Lesson study merupakan pembinaan profesi melalui pengkajian pembelajaran yang dilakukan secara kolegial kolaboratif dan berkelanjutan dalam rangka meningkatkan kualitas proses dan hasil belajar. Hasil akhir yang diharapkan dalam pembelajaran adalah peningkatan dan keseimbangan antara kemampuan soft skills dan hard skills peserta didik yang meliputi aspek kompetensi sikap, pengetahuan dan keterampilan. Kendala yang sering muncul dalam pembelajaran adalah masih rendahnya minat belajar siswa dan kurang tertarik dalam suatu proses pembelajaran dan juga seringkali guru tidak peka atau tidak mengetahui kendala yang dihadapi oleh anak murid secara spesifik sehingga perlu adanya metode analisis kasus pada praktek pembelajaran untuk mengetahui masalah-masalah dalam pembelajaran dan mencari solusi untuk memperbaikinya. Melalui Lesson study, guru dapat menciptakan proses pembelajaran yang interaktif, inspiratif, menyenangkan, menantang, memotivasi peserta didik untuk aktif, Fkreatif, mandiri sesuai bakat, minat dan perkembangan fisik \& psikologis peserta didik. Oleh karena itu, Penulis memutuskan untuk

A B S T R A C T

Lesson study is a professional development through a collaborative and continuous study of collegial learning in order to improve the quality of learning processes and outcomes. The final results expected in learning are improvement and balance between students' soft skills and hard skills which include competency aspects of attitudes, knowledge and skills. Constraints that often arise in learning are the low interest in learning students and less interested in a learning process and also often teachers are not sensitive or do not know the obstacles faced by students specifically so there is a need for case analysis methods in learning practices to find out the problems in learning and finding solutions to improve it. Through Lesson study, teachers can create learning processes that are interactive, inspiring, fun, challenging, motivating students to be active, creative, independent according to their talents, interests and physical \& psychological development of students. Therefore, the author decided to apply a lesson study to 7th grade students at SMP Negeri 1 Singaraja.

\section{Pendahuluan}

Pendidikan merupakan faktor utama dalam pembentukan pribadi manusia. Menyadari akan hal tersebut, Pemerintah sangat serius menangani pendidikan dan berusaha terus untuk meningkatkan kualitas pendidikan. Sebab dengan sistem pendidikan yang baik diharapkan generasi penerus bangsa yang berkualitas dan mampu mengadakan perubahan kearah yang lebih baik dalam kehidupan berbangsa dan bernegara. Dalam rangka meningkatkan mutu pendidikan tersebut pada tahun 2015, Pemerintah mengeluarkan Peraturan RI Nomor 19 tahun 2015 tentang standar Nasional Pendidikan. Peraturan ini merupakan usaha pemerintah untuk meningkatkan mutu pendidikan di Indonesia. Peraturan Pemerintah tersebut berbunyi: 1 . Proses pembelajaran pada satuan pendidikan diselenggarakan secara interaktif, inspiratif, menyenangkan, menantang, memotivasi peserta didik untuk berprestasi aktif serta memberikan ruang yang cukup bagi prakarsa, kreatifitas dan kemandirian sesuai bakat, minat dan perkembangan fisik serta psikologis peserta didik. 2. Dalam proses pembelajaran pendidik dituntut dapat memberikan keteladanan (sebagai panutan, contoh yang baik bagi peserta didik), 3. Setiap satuan pendidikan melakukan perencanaan proses pembelajaran, penilaian hasil pembelajaran, dan pengawasan proses pembelajaran untuk terlaksananya proses pembelajaran yang aktif dan dinamis.

Teori pendidikan merupakan landasan dan pijakan awal dalam pengembangan praktik pendidikan, misalnya pengembangan kurikulum, manajemen sekolah dan proses belajar mengajar. Kurikulum dan pembelajaran memiliki keterkaitan dengan teori pendidikan atau dalam penyusunan suatu kurikulum dan rencana pembelajaran ini mengacu pada teori pendidikan. Berbagai teori yang dikembangkan saat ini telah mewarnai proses dan praktik pendidikan. Sumbangsih para tokoh dalam menciptakan teori telah memberikan perkembangan dan kemajuan dalam proses pendidikan. Lahirnya teori dalam bidang pendidikan memberikan warna baru terhadap sistem pendidikan, proses belajar mengajar, manajemen sekolah dan metode pembelajaran. Adanya pergeseran metode dan pola didik pengajar terhadap peserta didik merupakan proses dari pelaksanaan teori dalam bidang pendidikan. Sebagai contoh berkembangnya pola pendidikan active learning dimana proses pembelajaran tidak hanya terpusat pada pengajar akan tetapi peserta didik mempunyai peranan sangat menentukan hasil belajar. Hal ini dipelopori oleh teori yang berkembang yaitu teori 
behaviorisme dimana setiap manusia mempunyai kemampuan untuk berfikir dan melakukan setiap aktifitas dalam proses belajar. Sehingga dengan teori ini setiap peserta didik diberikan ruang kebebasan untuk melakukan kegiatan yang disesuaikan dengan kemampuan peserta didik, tugas pengajar bersifat pengarah dan fasilitator, hal ini memungkinkan terbentuknya rasa percaya diri serta kemampuan peserta didik untuk menciptakan hal-hal yang inovatif dan kreatif (Sholichah, 2018).

Beberapa masalah guru yang dihadapi di Indonesia, salah satunya adalah kualitas guru (Dwi, 2016). Guru sebagai ujung tombak di lapangan (kelas) yang bersentuhan langsung dengan siswa dalam proses pembelajaran. Memahami situasi ini, pemerintah Indonesia telah membuat banyak program dan upaya untuk membantu guru meningkatkan keterampilan dan kemampuan mereka. Untuk meningkatkan profesionalisme mereka, guru dapat mengambil beberapa tindakan, seperti mengikuti seminar atau lokakarya, melakukan penelitian, serta melanjutkan studynya. Kegiatan lain yang dapat digunakan untuk mengatasi masalah ini adalah Lesson Study. Menurut Styler dan Hiebert (Susilo, 2019:3) mengatakan bahwa "Lesson study adalah suatu proses kolaboratif pada sekelompok guru ketika mengidentifikasi masalah pembelajaran, merancang suatu rancangan pembelajaran yang meliputi 1 . Kegiatan mencari buku dan referensi lainnya mengenai topik yang akan diajarkan, 2. Membelajarkan Peserta didik sesuai dengan Rancangan Pembelajaran (salah seorang guru melaksanakan pembelajaran sedangkan yang lain mengamati, mengevaluasi serta merevisi Rancangan pembelajaran). Kegiatan menulis dalam pengajaran bahasa kedua biasanya dianggap sebagai salah satu keterampilan yang nilai pentingnya terletak di bawah kemampuan berbicara, dan membaca. Menulis banyak digunakan sebagai cara untuk mempraktikkan unsur-unsur linguistik atau untuk mengekspresikan hal-hal yang bersifat personal bagi siswa (Ghazali, 2012:295). Untuk mengembangkan kemampuan menulis bahasa kedua, diperlukan pemahaman tentang cara menggabungkan komponen-komponen linguistik (pengetahuan tentang kosakata, tata bahasa, ortografi, struktur (genre)) agar dapat menghasilkan sebuah teks belajar sebagai suatu proses yang kompleks yang terjadi pada diri setiap orang sepanjang hidupnya.

Setelah diobservasi siswa kelas VII SMP Negeri 1 Singaraja masih mengalami kesulitan atau kurang mampu dalam pelajaran menulis berbahasa Inggris. Kesulitan ini disebabkan oleh siswa kurang paham ketika diberikan tugas menulis. Hal ini dapat dilihat dari banyaknya kertas kosong dalam waktu yang lama ketika siswa diberikan sebuah tugas menulis, kekurangan ide, dan lainnya karena tidak adanya stimulus yang diberikan, sehingga siswa mengalihkan kegiatan mereka mengobrol dengan temannya, sehingga menimbulkan keributan di dalam kelas. Mulai dari kurangnya minat, kurangnya sarana, kurangnya motivasi sehingga kurang serius dalam mengikuti mata pelajaran Bahasa Inggris sehingga berdampak pada lemahnya penguasaan kosa kata dan tata bahasa yang sangat diperlukan dalam pembelajaran aspek writing ini. Kalau melihat macetnya penulisan, itu berarti karena kurangnya pengorganisasian pokok pikiran.

Pelaksanaan lesson study untuk memperbaiki dan meningkatkan kualitas pembelajaran yang dilakukan. Lesson study merupakan pembinaan profesi yang dilaksanakan secara kolaboratif dan berkelanjutan yang bertujuan untuk meningkatkan kualitas proses dan hasil pembelajaran (Widodo, Sumarno, dan Nurjhani, 2007). Dari pernyataan-pernyataan tersebut dapat dsimpulkan bahwa lesson study adalah sebuah model pembinaan guru untuk meningkatkan kualitas pembelajaran. Pelaksanaan lesson study meliputi tahap plan (merencanakan), do (melaksanakan) dan see (merefleksi) yang diselenggarakan secara bersama-sama (kolektif) dan berkelanjutan yang melibatkan hampir semua komponen di dalam pembelajaran yang meliputi dosen pembina mata kuliah yang bertindak sebagai supervisor, guru pamong sebagai fasilitator pembelajaran serta mahasiswa baik yang bertindak sebagai model maupun yang bertindak sebagai observer. (Andini, 2016). Pada tahap plan dibahas rencana pembelajaran dalam bentuk chapter plan berdasarkan diskusi dengan seluruh komponen yang hadir dalam open plan. Tahap Do meliputi pelaksanaan dan observasi kegiatan pembelajaran berdasarkan chapter plan yang disusun untuk kemudian direfleksikan pada tahap see.

Pada setiap akhir putaran dilakukan identifikasi terhadap keterlaksanaan lesson study dan ketercapaian pembelajaran yang ditunjukkan oleh penilaian kognitif mahasiswa serta produk karya tulis pada akhir semester. Lesson Study bukan hal yang langka Di SMP N 1 Singaraja, Kegiatan ini telah dilakukan beberapa kali oleh guru maupun mahasiswa untuk mengetahui efektivitas proses pembelajaran. Melalui Tulisan ini, penulis bertujuan untuk melaporkan hasil lesson study yang telah diterapkan. Pelajaran atau penerapannya dilaksanakan di VIIa8, dan hasilnya serta detailnya akan dibahas secara rinci pada bab selanjutnya.

\section{Metode}

\section{Rancangan Penelitian}

Lesson study dilaksanakan di SMP N 1 Singaraja pada semester kedua tahun ajaran 2018/2019. Dalam Lesson Study ini, guru menggunakan kelas VIIa10 yang terdiri dari 32 siswa. Lesson study ini dilaksanakan sekali. Pelajaran di VIIa10 dilakukan pada hari Selasa, 26 Februari, 2019. Kelas dimulai 
pukul 09.20 hingga 10.40 dalam pelajaran ini, penulis mengambil peran sebagai guru model mata pelajaran bahasa Inggris. Tahap-tahap dalam melakukan Lesson Study terdiri dari tiga langkah yaitu perencanaan, pelaksanaan, see dan refleksi.

Pada tahap perencanaan, penulis sebagai guru model menyiapkan rencana pelaksanaan pembelajaran, merancang kegiatan pembelajaran, dan mengatur media, semua kegiatan tersebut dilakukan dalam satu kolaborasi dengan tim. Beberapa media yang disiapkan untuk membantu guru dalam menyampaikan topik pembelajaran yaitu: gambar dan audio. Pada tahap Pelaksanaan adalah tindakan atau implementasi perencanaan. Pada langkah ini, guru menyampaikan materi pembelajaran sementara pengamat (Dosen pembimbing, guru pamong dan teman-teman mahasiswa) melihat dan mengamati keseluruhan proses pembelajaran. Pengamat hanya akan melihat dan tidak diizinkan untuk melakukan interaksi langsung dengan siswa atau guru. Ada beberapa hal yang harus diperhatikan dalam Pelaksanaan, seperti: Guru model membagikan nomor atau name tag kepada peserta didik yang sesuai dengan urutan daftar hadir mereka, guru model mempresentasikan materi melalui media yang disiapkan berdasarkan perencanaan, Pengamat berdiri di belakang kelas dan mengamati interaksi siswa dengan guru, dan teman-teman mereka, Pengamat membuat beberapa catatan tentang kegiatan di kelas, Pengamat menulis nomor siswa untuk siswa dengan perilaku khusus (aktif dan tidak aktif), Pengamat dapat berkeliling untuk melihat interaksi siswa dalam kegiatan kelompok mereka, tetapi mereka tidak dapat berbicara dengan mereka, cukup mengamati.

Pada tahap see, seluruh tim akan membuat refleksi. Di sini, tim akan bersama membahas tentang hasil observasi pada tahap sebelumnya. Tim akan berdiskusi dalam dua sudut pandang, yaitu dari sisi guru dan sisi siswa. Ketika masalah ditemukan, tim akan membahas tentang solusi yang mungkin cocok untuk menangani atau memperbaiki masalah tersebut.

Dari hasil tahap see dapat diperoleh sejumlah pengetahuan baru atau keputusan-keputusan penting guna perbaikan dan peningkatan proses pembelajaran, baik pada tataran individual, maupun kelompok. Pada tataran individual, berbagai temuan dan masukan berharga yang disampaikan pada saat diskusi dalam tahapan refleksi (check) tentunya menjadi modal bagi guru model, baik yang bertindak sebagai pengajar maupun observer untuk mengembangkan proses pembelajaran ke arah lebih baik. Teknik Observasi menggunakan instrumen penelitian yang berupa lembar observasi dan catatan pengamat. Data dalam penelitian ini merupakan data kualitatif berupa catatan peneliti yang menggambarkan proses pembelajaran yang berlangsung dan tanggapan observer mengenai proses pembelajaran tersebut. Data kualitatif juga mencakup kendala-kendala yang dijumpai dalam implementasi lesson study berdasarkan RPP yang telah tersusun. Teknik observasi Lesson study dilakukan dalam satu tim. Tim ini terdiri dari satu guru yang akan mengajar di kelasnya, dan juga 5 orang pengamat (Dosen pembimbing, guru pamong dan 3 teman mahasiswa). Guru model membuat observasi menggunakan sudut pandang seorang guru, sementara pengamat akan melihat menggunakan sudut pandang guru dan siswa. Meski begitu, pengamat tidak bisa terlibat dalam proses pembelajaran.

Yang diperlukan dalam teknik pengumpulan data adalah Yang diperlukan dalam tahap ini adalah Rencana Pelaksanan Pembelajaran, dokumentasi dalam bentuk foto, media, game dan lembar kerja siswa. Foto dan rekaman diambil menggunakan ponsel. Rencana pelajaran, lembar kerja dan media diberikan di setiap langkah. Dan implementasinya akan didokumentasikan dalam foto.

\section{Hasil Dan Pembahasan}

Berdasarkan Topik penilitian ini adalah simple present tense terkait memberi dan meminta informasi mengenai fungsi dari profesi. Di kelas guru berkolaborasi dengan guru pamong, dosen pembimbing dan 3 rekan dosen dari program studi bahasa inggris.

Tabel 1. Waktu Lesson Study

\begin{tabular}{clc}
\hline $\begin{array}{l}\text { Wa } \\
\boldsymbol{k t u}\end{array}$ & Aktifitas & Tempat \\
\hline $20-2-$ & & \\
& & Aula SMP \\
& & Negeri 1 \\
& Membentuk tim lesson study & Singaraja \\
& Pemilihan guru model dan tim pengamat & \\
& Menentukan Kelas untuk penerapan Lesson Study \\
$22-$ & Menentukan waktu untuk implementasi lesson study & \\
$02-$ & Menentukan topik yang akan diajar & Kampus \\
2019 & Menentukan topik yang akan diajar & Undiksha
\end{tabular}


Mendiskusikan RPP dengan Pembimbing

Membuat Media Pembelajaran

26-02-

2019 Guru model menyiapkan Kelas dengan meminta siswa untuk menempelkan nomor urut masing-masing sesuai daftar hadir Guru model mengajar sesuai dengan kegiatan-kegiatan dalam RPP

Guru model memberikan refleksinya terlebih dahulu.

Pengamat memberikan hasil observasinya satu persatu

27-02- Guru dan pengamat mendiskusikan masalah yang mereka temukan

2019 didalam kelas

Guru dan pengamat mencari solusi untuk menanangani masalah tersebut dan memberikan saran untuk memperbaiki proses belajar mengajar di

Aula SMP

Negeri 1 pertemuan diberikutnya.

Singaraja

Penulis melakukan beberapa kegiatan dalam perencanaan serta bekerja sama dengan tim. Tahap ini dilakukan pada 20 Februari, 2019. Pertama, penulis berdiskusi dengan pembimbing dan guru pamong tentang kemungkinan waktu dan konsep pembelajaran. Pada tahap ini, penulis memutuskan menggunakan kelas VIIa10 sebagai objek Lesson Study. Kemudian, penulis memutuskan untuk menggunakan materi "simple present tense" sebagai topik utama penelitian.

Selama tahap ini, penulis dan teman-teman membahas tentang metode dan strategi yang akan digunakan. Tujuan dari kegiatan ini adalah untuk melatih keterampilan siswa dalam berinteraksi menggunakan simple present tense, khususnya dalam menanyakan fungsi atau tingkah laku dari orangorang sekitar. Pada tahap ini, penulis juga menyusun Rencana Pelaksanaan Pelajaran (RPP). Gambar dan audio dipilih sebagai media utama. Kegiatan untuk meningkatkan pengetahuan siswa dilakukan secara individu sedangkan untuk keterampilannya dilakukan secara berpasangan.

Lesson study dilakukan dengan lancar di VIIa10 pada hari Selasa, tgl 26 februari 2019. Pertama, guru membagikan nomor urut kepada siswa sebelum kelas dimulai. Pada pukul 09.20, kelas dimulai. Guru membuka kelas dengan berdoa bersama, memeriksa kehadiran, dan memberikan brainstorming kepada peserta didik dengan cara menunjukan 2 gambar untuk siswa mengingat atau mereview kembali materi yang telah diberikan pada pertemuan sebelumnya. Kemudian guru memberi penjelasan tambahan kepada peserta didik mengenai struktur simple present tense dan peserta didik diberikan kesempatan untuk memberikan contoh sesuai dengan materi yang disampaikan.Dalam ranah pengetahuannya, Guru membagikan sebuah dialog rumpang kepada masing-masing peserta didik dan kemudian guru memutarkan sebuah audio yang berisi percakapan mengenai meminta dan memberi informasi terkait fungsi dan tindakan orang. Dalam kegiatan ini, Peserta didik diminta untuk mendengarkan dialog tersebut dengan teliti untuk melengkapi unsur kebahasaan dan struktur teks dialog tersebut menggunakan simple present tense.

Audio ini diputarkan tiga kali sampai peserta didik benar-benar menyelesaikan dan mengisi semua bagian yang rumpang. Selanjutnya, Guru dan peserta didik berdiskusi bersama-sama mengenai dialog yang telah dilengkapi, kemudian peserta didik diberikan kesempatan untuk menanyakan hal-hal yang belum dipahami dalam sturktur kalimat simple present tense. Pada bagian ini, guru menjawab dan memberikan penjelasan secara detail kepada siswa. Setelah itu peserta didik memainkan sebuah game, dalam game ini masing-masing peserta didik diberikan sebuah sticky note dan masing-masing siswa membuat 1 kalimat simple present kemudian menempelkannya pada papan. Kegiatan ini untuk mengetest kemampuan siswa dalam penguasaan struktur dan unsur kebahasaan dari simple present tense. Tugas selanjutnya atau kegiatan kedua adalah ranah keterampilan. Dalam kegiatan ini, guru mengarahkan peserta didik secara berpasangan membuat dialog terkait memberi dan meminta informasi mengenai profesi orangtuanya menggunakan simple present tense. Dan kemudian selanjutnya, peserta didik diberi waktu untuk mendemonstrasikan dialog yang telah dibuat didepan kelas secara berpasangan. Dalam hal ini, guru memiliki kesempatan untuk menilai hasil pembelajaran menggunakan rubrik penilaian yang telah disiapkan dalam Rencana Pelaksanaan Pembelajaran.

Keseluruhan proses pembelajaran sesuai dengan rencana pelajaran. Guru mengajar sesuai dengan langkah-langkah dalam perencanaan. Semua kegiatan yang terdapat pada rencana pelajaran dapat diterapkan selama bagian ini. Manajemen waktu juga bagus. Waktu yang tersedia dapat dimaksimalkan dan mencakup semua kegiatan yang dibutuhkan. 
Siswa terlibat aktif dalam proses pembelajaran. Mulai dari apersepsi sampai akhir. Siswa mengamati beberapa gambar terkait apersepsi dengan sopan dan peduli. Siswa ikut serta dalam menjawab pertanyaan guru. Siswa antusias dalam mendengarkan penjelasan serta arahan guru. Mereka tetap diam dan mendengarkan audio dengan cermat di kegiatan pertama. Bagian diskusi tentang kegiatan pertama juga efektif. Semua siswa mengambil bagian dalam menyelesaikan tugasnya. Pada bagian kedua, siswa tampak aktif dalam bekerja berpasangan. Mereka menyampaikan dan membagikan ide-ide mereka, menggunakan imajinasi mereka, dan menjadi kreatif. Mereka menunjukkan kepercayaan diri yang baik selama bagian presentasi juga, di mana pendengar lain tampaknya reaktif dan aktif.

Tujuan dari proses pembelajaran dapat dicapai. Itu dapat dilihat di akhir kelas di mana siswa dapat membuat suatu teks dialog secara berpasangan dan medemonstrasikannya di depan kelas. Selama bagian pertama, siswa juga dapat menerapkan pengetahuan mereka dengan menggunakan unsur kebahasaan (simple present) yang tepat dalam melengkapi dialog tentang memberi dan meminta informasi mengenai profesi orang. Hal yang sama juga terjadi pada bagian presentasi. Siswa menunjukkan prestasi dan kinerja yang baik dalam melaksanakannya. Secara keseluruhan, siswa dapat mencapai tujuan pembelajaran yang dibuat oleh guru.

Ada beberapa masalah yang ditemukan oleh guru model dan pengamat. Kelemahan dan masalah tercantum dalam tabel ini:

Tabel 2. Kelemahan dan solusi

\begin{tabular}{lll}
\hline No & Kelemahan & Solusi yang disarankan \\
\hline 1. & Volume berbicara Guru model cukup pelan & $\begin{array}{l}\text { Guru diharapkan untuk berbicara } \\
\text { lebih keras }\end{array}$ \\
2. & $\begin{array}{l}\text { Beberapa siswa sedikit bingung atau kurang harus menjelaskan instruksi } \\
\text { mengerti dengan instruksi yang diberikan guru } \\
\text { secara jelas dan berulang-berulang } \\
\text { sampai siswa paham. Guru } \\
\text { memastikan siswa sudah paham baru } \\
\text { mulai mengerjakan tugas }\end{array}$ \\
3. & $\begin{array}{l}\text { Masih ada peserta didik yang malu-malu dalam } \\
\text { berpatisipasi seperti dalam menjawab arus lebih bisa membuat siswa } \\
\text { pertanyaan }\end{array}$ &
\end{tabular}

Guru model melakukan refleksi atau feedback terhadap segala masukan yang telah diberi oleh para observer dan diterima oleh guru model sebagai bahan referensi. Di Tahap ini, Guru Mulai memperbaiki kesalahan yang dilakukan sebelumya. Contohnya: Guru mulai berbicara dengan suara yang jelas pada pertemuan berikutnya, guru juga mulai memberikan instruksi yang lebih jelas disaat memberikan tugas kepada peserta didik dan guru memberika reward kepada peserta didik sehingga mereka mau lebih aktif dan percaya diri

\section{Simpulan}

Berdasarkan pembahasan dan refleksi yang telah diuraikan, dapat disimpulkan bahwa Lesson study merupakan upaya proses peningkatan pembelajaran secara kolaboratif dan berkelanjutan berlandaskan prinsip-prinsip kolegalitas dan mutual learning. Berdasarkan hasil penelitian, model ini bermanfaat dalam meningkatkan kualitas pembelajaran pada mata pelajaran bahasa Inggris pada kelas VII. Adapun manfaatnya, yaitu: Peningkatan kemampuan guru dalam merancang pembelajaran dimana pembelajaran yang dirancang mampu menciptakan cooperative dan collaborative learning dalam kelompok, Peningkatan kemampuan guru dalam mengobservasi kelas dimana tim lesson study telah mampu mendiskusikan bagaimana peserta didik belajar dan telah belajar dari satu sama lain bagaimana membelajarkan peserta didik dengan lebih baik, Peningkatan aktifitas peserta didik dalam setiap kegiatan, Peningkatan hubungan kolegalitas antar guru.

Berdasarkan pembahasan di atas dapat disarankan hal-hal berikut : Guru perlu belajar melakukan pengamatan mengenai apakah peserta didik benar-benar belajar dan terfokus pada kegiatan peserta didik karena ada kecenderungan guru lebih mencermati mengenai materi daripada mengenai kegiatan peserta didik, Mencermati kelebihan-kelebihan yang diperoleh setiap peserta didik dalam melakukan kegiatan berdiskusi berpasangan, Mencermati manfaat yang diperoleh Guru-guru pengamat melalui kegiatan lesson study.

\section{Daftar Pustaka}

Sholichah, A. S. (2018) 'Teori-Teori Pendidikan Dalam Al-Qur'an', Edukasi Islami : Jurnal Pendidikan Islam, 7(01), p. 23. doi: 10.30868/ei.v7i01.209. 
Conference Primary Education Research Pivotal Literature and Research UNNES 2018 (IC PEOPLE UNNES 2018). Atlantis Press.

Mardianis, M. (2018). Upaya Meningkatkan Kompetensi Guru Dalam Menerapkan Pembelajaran Lesson Study Melalui Workshop Di SD Negeri 02 Ampalu Kecamatan Lareh Sago Halaban.

Miharja, F. J., Hindun, I., Wahyono, P., Nurwidodo, N., \& Susetyarini, E. (2017). Lesson Study Based Practical Development for Prospective Teachers in Higher Education.

Pemerintah, P., \& No, R. I. (19). Tahun 2005 tentang Standar Nasional Pendidikan.

Setijawati, U. (2019, February). Lesson Study Based Learning Can Develop Conservation Characters, Activities, And Learning Outcomes. In International

Subadi, T., \& Hidayati, E. F. (2013). Lesson Study sebagai inovasi pendidikan. 